\title{
ОЦІНКА СУДАМИ ФОТОЗНІМКІВ ЯК ЕЛЕКТРОННИХ ДОКАЗІВ У ГОСПОДАРСЬКОМУ ПРОЦЕСІ
}

\author{
БАРАНОВСЬКА Віра Михайлівна - кандидат юридичних наук, доцент, \\ професор кафедри Цивільно-правових дисциплін та міжнародного права \\ Навчально-наукового інституту права ім. князя Володимира Великого
}

УДК 346.93

DOI 10.32782/LAW.UA.2021.4.22

Статья посвящена исследованию использования участниками процесса фотоснимков в качестве электроннъгх доказательств в хозяйственном судопроизводстве Украинъ, предоставлена характеристика фотооснимков как вида электронньх доказательств и проведен анализ исследования судами фотоснимков в качестве электронных доказательств в хозяйственном судопроизводстве Украинъл. Автором освещень основные проблемные моменты, существуюшие в настоящее время при использовании участниками дела фотоснимков в качестве доказательств в хозяйственном прочессе Украинъ.

Ключевъие слова: электроннъле улики, ботоснимки, ботобиксаиия.

Постановка проблеми

3 надзвичайно швидким та різноманітним розвитком i поширенням цифрових технологій в усі сфери суспільного життя, їх використання як у життєдіяльності людей, так і підприємств, спричинило появу все нових і нових видів електронних доказів.

Так, сьогодні в судовій системі України електронні докази $є$ найбільш використовуваним учасниками судового розгляду видом доказів. Аналіз судової практики свідчить, що найпоширенішими видами електронних доказів, які сторони використовують для доведення своїх правових позицій, є фотографії, скріншоти, відео- та звукозаписи.

Основними особливостями електронних доказів, які допомагають учасникам справи у їх використанні як доказів, є те, що вони існують в нематеріальному вигляді; копіюються чи переносяться на різні пристрої без втрати змісту та характеристик, а тому й можуть існувати в кількох місцях одночасно; для їх відтворення необхідне використання відповідних технічних засобів.

Варто зазначити, що вже тривалий час залишається не врегульованим на законодавчому рівні питання щодо порядку оформлення, подання та дослідження електронних доказів, що у свою чергу, спричиняє різну судову практику з цього приводу.

Аналіз останніх досліджень і публікацій

Дослідженню інституту електронних доказів були присвячені праці Булгакової I.B., Блажівської Н.Є., Боннер О.Т., Вєршиніна О.П., Ворожбит С.П., Горєлова М.В., Мітрофанової М.О., Фурси С.Я. та інших. Однак, досліджені питання в працях вищевказаних науковців щодо фотознімків наданих в якості електронних доказів на цей час не в повній мірі відповідають сучасному стану розвитку інформаційних технологій, а тому в цій статті буде здійснено дослідження сучасного стану використання фотознімків як доказів у господарському процесі України та здійснений аналіз їх оцінки господарськими судами України.

Не вирішені раніше проблеми

Питання можливості використання фотознімків як доказів у господарському судо- 


\section{Цивільне, підприсмницьке, господарське та трудове право}

чинстві далеко не нове, проте, тривалий час воно не втрачає своєї актуальності, з огляду на необхідність у правильному використанні та поданні фотознімку як доказу в судовому процесі.

Метою дослідження в цій статті є встановлення, з урахуванням судової практики, юридичної сили фотознімків як доказів у господарському судочинстві України.

\section{Виклад основного матеріалу}

У зв'язку з відсутністю в ГПК України обов'язкових реквізитів, які мають бути в електронних доказах, також виникають певні колізії в законодавстві, які суди вирішують на власний розсуд.

Частиною 2 статті 8 Закону України «Про електронні документи та електронний документообіг» чітко встановлена норма, згідно 3 якою допустимість електронного документу як доказу не може бути спростована лише на підставі того, що він має електронну форму [1].

Однак, це правило не набуло відповідного поширення в судовій практиці та, відповідно, вказаної норми недостатньо для формування єдиної правової позиції щодо використання фотознімків як електронних доказів у господарському судочинстві України.

Так, Касаційний господарський суд у складі Верховного суду в постанові від 12.06.2018 у справі №908/1120/17 при перевірці правильності дослідження судом апеляційної інстанції електронних доказів зазначив наступне.

Огляд у судовому засіданні судом апеляційної інстанції CD-диска з фото та відеозаписом показав, що цей електронний доказ також не містить інформації про події недопуску позивача та третіх осіб до реєстрації посадовими особами відповідача та/або реєстраційною комісією відповідача 18.04.2017 року. Крім того, надане позивачем відео не може вважатися належним та достатнім доказом фіксування відповідних подій, оскільки не містить необхідних реквізитів електронного доказу, як то фіксації дати та часу зйомки, місця події тощо [2].
Тобто суд не взяв до уваги електронний доказ у зв’язку з відсутністю необхідних реквізитів.

Необхідними умовами для прийняття судом фотознімків як електронних доказів є:

- приналежність до цього спору;

- інформативність, тобто має бути зрозуміло, де, коли, за яких умов виконаний даний фотознімок;

- отриманий 3 дотриманням вимог законодавства;

- бути оригінальним.

Варто пам'ятати, щоб фотознімки були долучені до матеріалів справи та оцінені судом під час вирішення справи, останні мають бути отриманні без порушення вимог законодавства. В іншому ж випадку вони не будуть мати юридичної сили.

Рішення про прийняття фотознімків як електронних доказів приймається тільки на розсуд суду.

Особливу увагу при прийнятті фотознімків як електронних доказів суди звертають на їх достовірність, з огляду на те, що в сучасному суспільстві досить легко вносити до них зміни чи робити монтаж. 3 огляду на вказане, досить часто виникає необхідність у проведенні експертного дослідження для виявлення фактів фальсифікації.

У процесі експертного дослідження експерт з’ясовує наступні відомості:

- де та коли було зроблено фотознімок;

- за яких умов здійснювалася фотозйомка та за допомогою якого технічного засобу;

- чи є цей фотознімок оригінальним або ж копією;

- чи наявний монтаж або ретуш;

- за допомогою якого устаткування фотографії виготовлені на папері.

При проведенні експертного дослідження використовуються спеціальні інструменти, лабораторне обладнання та апаратура. На підставі результатів дослідження складається експертний висновок, який приймається судом як доказ.

Оцінюючи фотознімки як електронних доказів, суд з'ясовує наступні елементи:

- чи видається можливим встановити, коли, де і за яких обставин зроблений фото знімок; 
- чи не порушено під час зйомки таємниця особистого життя громадянина;

- чи є фото справжнім (оригінальним).

Проаналізуємо наявну судову практику щодо дослідження судами фотознимків як електронних доказів в господарському судочинстві України.

Так, Господарський суд Одеської області у рішенні від 21.05.2021 по справі№ 916/3110/20 зазначив, про дослідження судом змісту електронного доказу, а саме фото лічильників у застосунку-месенджері «Viber», що знаходиться в мобільному телефоні керівника Приватного підприємства «Сервісна компанія «Комфорт-Одеса» ОСОБА_1, про що складено Протокол вчинення окремої процесуальної дії.

При цьому, у такому рішенні відображено, що під час огляду мобільного телефону здійснювалася фотофіксація процесу. Судом під час дослідження встановлено, що на вказаний мобільний телефон за допомогою застосунку-месенджера «Viber» від контакта «ОСОБА_2 " 3 номера мобільного телефону НОМЕР_3 02.04.2021 о 7:20 надходили фото лічильників на мобільний телефон ОСОБА_1 /т. II а.с. 41-44/. 3 фото № 5, яке є додатком до Протоколу окремої процесуальної дії від 07.04.2021, вбачається, що покази приладу обліку - Ultraheat T550/UH50 (заводський номер 69194426) дорівнюють 4614,98 Гдж./т. II а.c. 44/ [3].

У рішенні Господарського суду Аьвівської області від 29.12.2020 у справі№ 914/1783/20 суд 3 долучених до матеріалів справи електронних доказів, а саме фотофіксації порушення та відеозапису встановив, що дійсно на з єднані газопроводу до лічильника встановлено лише одну пломбу №R26965392, водночас пломба відділу економічної безпеки №70919007 є відсутньою взагалі.

Крім того, у вказаному рішенні суд надаючи правову оцінку долученим позивачем до матеріалів справи фото та відеофіксації порушення, в сукупності з іншими доказами, зазначив, що такі в цілому підтверджують факт відсутності на спірному вузлі обліку згаданої вище пломби відділу безпеки, однак не дають підстав стверджувати, що наявна на пломбувальному дроті пломба №R26965392 є підробною [4].

Господарський суд міста Києва у рішенні від 13.01.2020 у справі №910/14987/19 не прийняв як належні та допустимі докази по справі надані позивачем роздруківки фото із мережі Інтернет за жовтень 2011 року та червень 2015 року з посиланням на ч. 2 ст. 96 Господарського процесуального кодексу України, якою передбачено, що електронні докази подаються в оригіналі або в електронній копії, засвідченій електронним цифровим підписом, прирівняним до власноручного підпису відповідно до Закону України «Про електронний цифровий підпис». Законом може бути передбачено інший порядок засвідчення електронної копії електронного доказу [5].

Господарський суд Аьвівської області у рішенні від 28.01.2021 у справі№ 914/2001/20, задовольняючи позовні вимоги зазначив, що факт порушення цілісності пломбувального матеріалу є очевидним та підтверджується фото- та відеоматеріалами, доданими до акту [6].

У рішенні Господарського суду Харківської області від 04.03.2021 у справі№ 922/185/21 суд критично віднісся до посилань позивача на те, що ним направлялись рахунки-акти за спірний період відповідачу за допомогою програми «M.E.Doc.», оскільки, доказів наявності між сторонами згоди на направлення рахунків саме в такій формі матеріали справи не містять та позивачем суду не надано, тоді як відповідач, зокрема у відзиві на позов та запереченнях зазначені обставини заперечує, та зазначає, що будьяких рахунків на його адресу у вказаний період не надходило.

У цьому рішенні суд зазначив, що посилання позивача з цього приводу на фото екрану комп ютера, з якого нібито направлялися такі рахунки, також не доводять зазначених обставин, оскільки в силу положень ч. 1 ст. 77 ГПК України обставини, які відповідно до законодавства повинні бути підтверджені певними засобами доказування, не можуть підтверджуватися іншими засобами доказування. У цьому випадку фото екрану комп ютера не вважаються належ- 


\section{Цивільне, підприємницьке, господарське та трудове право}

ними доказами обставин, на існуванні яких наполягає позивач [7].

Господарський суд міста Києва під час судового розгляду справи № 910/10995/19 ухвалою суду від 21.11.2019 зобов язав сторони провести в місці знаходження спільний огляд з фотофіксацією мобільної гідравлічної рампи AUSBAU-SPCL20-2SL; за результатами огляду 3 фото фіксацією скласти акт огляду та надати його суду до 04.12.19.

У рішенні ж суд дійшов висновку, що системний аналіз характеристик рампи AUSBAU-SPCL20-2SL серійний номер va25 наведених «Керівництві 3 експлуатації мобільних гідравлічних рамп AUSBAU-PRO» i виявленого представниками сторін в AКТI, Схемі до Акту і фото таблицях вказує на недотримання виробником технічних параметрів рампи [8].

Господарський суд Одеської області у рішенні від 28.04.2021 у справі № 916/3549/20 зазначив, що наданий позивачем фотозвіт не відповідає визначеним законодавством критеріям належності доказів, оскільки не містить обов 'язкових реквізитів електронного доказу ні часу та дати зйомки, ні жодних вказівних знаків, які 6 надали можливість ідентифікувати адресу місця фіксації [9].

\section{Висновки}

Аналізуючи вищевикладені судові рішення, можна дійти висновку, що на цей час існуе нагальна проблема на рівні законодавчого закріплення визначення обов'язкових елементів, які необхідні мати фотознімки, у т.ч. й інші електронні докази, для їх використання учасниками спірних правовідносин як достовірних та належних доказів.

При цьому, варто зазначити, що на законодавчому рівні відсутня чітка процедура щодо порядку оформлення, подання та дослідження електронних доказів.

Крім того, враховуючи, що електронний доказ можна легко знищити, питання про те, як правильно та надійно зберегти, а також надати його суду, залишається відкритим.

\section{Мiтература}

1. Про електронні документи та електронний документообіг: Закон України від 22.05.2003 № 851-15 [Електронний ресурс] // Верховна Рада України. Офіційний вебпортал. Режим доступу: http://zakon0.rada. gov.ua/laws/show/851-15 - Назва з екрана.

2. Постанова Касаційного господарського суду у складі Верховного суду від 12.06.2018 у справі №908/1120/17 [Електронний ресурс] - Режим доступу: http://reyestr. court.gov.ua/Review/74671049 - Назва з екранy.

3. Рішення Господарського суду Одеської області від 21.05.2021 у справі № 916/3110/20 [Електронний ресурс] - Режим доступу: https://reyestr.court.gov.ua/Review/97349635 Назва з екрану.

4. Рішення Господарського суду Аьвівської області від 29.12.2020 у справі№ 914/1783/20 [Електронний ресурс] - Peжим доступу: https://reyestr.court.gov.ua/ Review/93962475 - Назва з екрану.

5. Рішення Господарського суду міста Києва від 13.01.2020 у справі №910/14987/19 [Електронний ресурс] - Режим доступу: https://reyestr.court.gov.ua/Review/86853303 Назва з екрану.

6. Рішення Господарського суду Аьвівської області від 28.01.2021 у справі- № 914/2001/20 [Електронний ресурс] - Режим доступу: https://reyestr.court.gov.ua/ Review/95103254 - Назва з екрану.

7. Рішення Господарського суду Харківської області від 04.03.2021 у справі № 922/185/21 [Електронний ресурс] - Peжим доступу: https://reyestr.court.gov.ua/ Review/95304914 - Назва з екрану.

8. Рішення Господарського суду міста Києва від 20.10.2020 у справі № 910/10995/19 [Електронний ресурс] - Режим доступу: https://reyestr.court.gov.ua/Review/92526283 Назва з екрану.

9. Рішення Господарського суду Одеської області від 28.04.2021 у справі № 916/3549/20 [Електронний ресурс] - Режим доступу: https://reyestr.court.gov.ua/Review/96880087 Назва з екрану. 


\begin{tabular}{|c|}
\hline АНОТАЦІЯ \\
\hline Стаття присвячена дослідженню ви- \\
\hline користання учасниками судового процесу \\
\hline ботознімків як електронних доказів у госпо- \\
\hline дарсъкому судочинстві Украӥни, надано ха- \\
\hline рактеристику фотознімкам як виду електро- \\
\hline нних доказів та здійснено аналіз дослідження \\
\hline судами ботознімків як електронних доказів \\
\hline у господарсъкому судочинстві Украӥни. Автор \\
\hline висвітлив основні проблемні моменти, які ic- \\
\hline нують на ией час при використанні учасника- \\
\hline ми справи фоотознімків як доказів у господар- \\
\hline съкому прочесі Украйни. \\
\hline $\begin{array}{l}\text { Ключові слова: електронні докази, бото- } \\
\text { знімки, фото фіксачія. }\end{array}$ \\
\hline
\end{tabular}

Baranovskaya $\mathbf{V}$.

Ph.D., Associate Professor of the Ministry of Education and Science,

Professor of the Department of Civil Law Disciplines and International Law Educational and Scientific Institute of Law named after Prince Vladimir the Great

An extended abstract of a paper on the subject of:

«Evaluation by courts of photographs as electronic evidence in the economic process»

Modern society it is impossible to imagine without the informative computer systems.

These systems have ability to keep, to pass and carry digital information.

Taking into account the level of the informative computer systems actual enough there is an institute of electronic proofs.
The amount of electronic data that can come forward as proofs increases with development of society and informative computer systems.

A publication is sanctified to the institute of electronic proofs in economic courts, complex description to the indicated institute is given.

This article examines to the study of the use of photographs as electronic evidence in commercial litigation of Ukraine, characterizes photographs as a type of electronic evidence and analyzes the study of court photographs as electronic evidence in commercial litigation of Ukraine. The author highlights the main problems that currently exist in the use of photographs by participants in the case as evidence in the economic process of Ukraine.

Analyzing the court decisions, it was concluded that there is currently an urgent problem at the level of legislative consolidation of the definition of mandatory elements that are required to have photographs, including and other electronic evidence, for their use by the parties to the disputed legal relationship as reliable and appropriate evidence.

It is noted that at the legislative level there is no clear procedure for the procedure for registration, submission and examination of electronic evidence.

In addition, given that electronic evidence can be easily destroyed, the question of how to safely and securely preserve it and provide it to the court remains open.

Key words: electronic evidence, photographs, photo fixation. 